\section{Performance of Cobb 500 broiler chicks feed by Chamomile alcoholic extract}

\author{
Yaser Rahimian, 1 Mosa Moeini, ${ }^{2}$ \\ Saeed Moradi, ${ }^{3}$ Yasamin Miri, ${ }^{4}$ \\ Saeed Masoud Davoodi ${ }^{5}$
}

1Department of Animal Sciences, Shahrekord Branch, Islamic Azad University, Shahrekord; 2Department of Animal Sciences, Faculty of Agriculture, Abhar Branch, Islamic Azad University, Abhar; 3Department of Animal Sciences, Faculty of Agriculture, Varamin Branch, Islamic Azad University, Varamin; ${ }_{4}^{4}$ Department of Plant Ecophysyology, Faculty of Agriculture, University of Tabriz, Tabriz; 5Department of Animal Sciences, Faculty of Agriculture, Shahinshahr Branch, Islamic Azad University, Shahinshahr, Iran

\begin{abstract}
This study was performed to evaluate the effect of chamomile alcoholic extract on performance, some blood parameters and intestinal characteristics of broiler chicks. A total 320 one day old Cobb 500 broiler chicks were randomly divided into 4 treatments. Treatments were further divided into 4 replicates. Chicks were fed a basal diet as control group, basal diet with $0.3 \%$ chamomile extract (S1), basal diet with $0.5 \%$ chamomile extracts (S2) and basal diet with $0.7 \%$ chamomile extract (S3). The experiment was carried out of 42 days. Feed intake FI and body weight gain BW was calculated for estimation of feed conversion ratio FCR. At the end of experimental period (42 days), to determine carcass traits and other parameters, 2 birds form each replicate were slaughtered. Additionally, the blood serum samples were subjected to biochemical analysis. For determination intestinal characteristics, small intestine tissues were collected. Data from this study showed that improvement of body weight gain and feed conversion were found in chamomile extract groups $(\mathrm{P}<0.05)$. There were significant differences between carcasses traits in treatments feed by chamomile extract. As result reveled from this study serum triglyceride, cholesterol LDL decreased in groups fed by chamomile alcoholic extract and HDL increased significantly $(\mathrm{P}<0.05)$ instead. In addition, villus height decreased in S1and S2 groups. An increasing crypt depth was seen on S2 According to these data villus widths,
\end{abstract}

epithelium layer and goblet cells increased by using chamomile extract specially by using S2. In conclusion, we could demonstrate that chamomile alcoholic extract may be used as ingredient in broilers ration without harming effects on carcass characteristics, blood biochemical parameters, and intestinal morphology of Ross 308 broiler chicks.

\section{Introduction}

Chamomile (Matricariachamomilla) has been used in ethno medicine throughout history. It belongs to a major group of cultivated medicinal plants. ${ }^{1}$ It contains some group of active compound classes such as sesquiterpenes, flavonoids, poly acetylenes and coumarins. Herniarin and umbelliferone (coumarin), caffeic acid (phenylpropanoids) and chlorogenic acid, apigenin, apigenin-7-O-glucoside, luteolin and luteolin7-Oglucoside (flavones), quercetin and rutin (flavonols), and naringenin (flavanone) are found in chamomile extract. The coumarins are represented in chamomile by herniarin, umbelliferone, and (Z) - and (E)2 - $\beta$-d-glucopyranosyloxy-4-methoxycinnamic acid, the glucoside precursor of herniarin, were described as native compounds in chamomile. 2,3 Kolacz et al. showed that chamomile flowers inhibit the excessive growth of intestinal harmful microorganism, thus counteracting inflammation. ${ }^{4} \mathrm{Abo}$ Omar et al. ${ }^{5}$ showed that supplementation of chamomile flowers at level of $2.5 \mathrm{~kg} / \mathrm{ton}$ of broiler diet improved growth performance and feed conversion. Natural feed additives had beneficial effect for stimulation and activity of digestive system by improving the diet palatability and enhancing appetite of poultry, thus increasing the amount of feed consumed.6,7 The pharmacological action of herbal extracts and their active materials in humans is also well known, but in animal nutrition the number of precise experiments is relatively low. ${ }^{8}$ For this reason, the objective of this study was to explore the potential uses of chamomile alcoholic extract on performance, some blood parameters and intestinal morphology in Ross 308 broiler chicks.

\section{Materials and Methods}

The present study was conducted during 42 days at poultry farm of veterinary college, Islamic Azad University, Shahrekord branch, Shahrekord, Iran
Correspondence: Yaser Rahimian, Department of Animal Sciences, Islamic Azad University, Shahrekord Branch, Shahrekord, Iran.

E-mail: yas.rahimiyan.yr@gmail.com

Key words: Blood biochemical, Broilers, Chamomile extract, Performance, Intestinal characteristics.

Acknowledgments: The authors sincerely acknowledge for the partially helps provided by Islamic Azad University, Shahrekord, Iran for the cooperation and assistance us to in order to run this test.

Contributions: the authors contributed equally.

Conflict of interest: the authors declare no potential conflict of interest.

Funding: none.

Received for publication: 9 December 2017 Accepted for publication: 25 June 2018.

This work is licensed under a Creative Commons Attribution NonCommercial 4.0 License (CC BY-NC 4.0).

C) Copyright Y. Rahimian et al., 2018

Licensee PAGEPress srl, Italy

Veterinary Science Development 2018; 8:7529

doi:10.4081/vsd.2018.7529

\section{Experimental plan}

A total of 320 commercial (Ross 308) days old male (sexed) Cobb 500 broiler chicks were divided into four treatment groups and were further subdivided into four replicates. The experiment was done due 01.05.2017 to 12.06.2017. Chamomile flowers obtained from herbalists, cleaned and powdered then extracted according to Harborne's method, ${ }^{9}$ then mixed with the experimental diets. The treatments were divided as basal diet with no chamomile extract kept as control; basal diet $+0.3 \%$ of chamomile extract (S1), basal diet $+0.5 \%$ of sumacs chamomile (S2), basal diet $+0.7 \%$ chamomile extracts (S3). All diets of each period were prepared with thesame compositionand they were isoenergic and isocaleric. Diets were formulated to meet or exceed the requirements of NRC recommendations. ${ }^{10}$ Also, feed and fresh water was provided ad libitum during this experiment.

\section{Data collection}

The data on growth performance were collected for the following parameters:body weight $(\mathrm{g})$, feed intake $(\mathrm{g})$, feed conversion ratio $(\mathrm{g})$, carcass yield $(\%)$, and edible part weight $(\mathrm{g})$. The body weight of individual bird was recorded on weekly basis. Daily 
feed intake was calculated for estimation of weekly feed conversion ratio (FCR). At the end of experimental period, two birds form each replicate were slaughtered for determination of carcass traits and other parameters. Body parts were separated and weighed as percentage weight. Dressing percentage was calculated free from giblets and the organs were weighed separately as percentage of carcass weight. The point spread, performance index and production efficiency factor were also calculated for evaluating the growth performance. The blood samples were taken from the brachial vein from two birds per replicate and stored at refrigerator at $4^{\circ} \mathrm{C}$. Also, the blood serum samples were subjected to biochemical analysis for blood parameters by Pars Azmoon commercial kits. The internal organs were removed after slaughter. Final samples from small intestine tissue were collected for determination of intestinal characteristics. Final samples from small intestine tissue were collected for determination intestinal characteristics such as villus height, crypt depth, villus width, epithelium layer and goblet cells. The histomorphometric investigation was performed by light microscopy, and the measurement was done using public domain image analysis software (Image J, National Institute of Mental Health, Bethesda, MD, USA). ${ }^{11}$

\section{Statistical analysis}

Data were collected and analyzed using the General Linear Model Procedure (GLM) and the comparison of means was made through Duncan's Multiple Range by using SAS 9.1 software. ${ }^{12}$ See Table 1 for details on the composition of the experimental diets for broiler chicks.

\section{Results and Discussion}

Table 2 describes the effect of added experimental diets on broilers performance.

\section{Performance}

The data which obtained from performance of broiler chickens fed by chamomile extract are shown in Table 1. Data showed that use of S1, S2 and S3 increased FI significantly $(\mathrm{P}<0.05)$ compared to control group. Body weight gain and initial live weight were also significantly higher $(\mathrm{P}<0.05)$ in treated groups.

Cabuk et al. ${ }^{13}$ noted that the herbal essential oil mixture may be considered a potential growth promoter. Skomorucha and Sosnowka-Czajka ${ }^{14}$ showed some positive effect of the addition of $2 \mathrm{~mL} \cdot 1 / \mathrm{L}$ chamomile in drinking water on broiler chicken visceral organs.

Mansob showed that using different levels sumac had significant effects on food intake, weigh improvement, average of weight and feed conversion of broilers $(\mathrm{P} \leq 0.05) .15$

Overall means in Table 2 showed significant difference in body weight among treatments $(\mathrm{P}<0.05)$. Ahmadian-Attari et al. ${ }^{16}$ showed that use of herbal extract can improve growth and have beneficial effect on broilers.

The improvement of body weight gain and feed conversion ration are due to the active compounds such as cinnamaldehyde and ugenol that they found in chamomile, and they are causing better efficiency in the utilization of nutrients and resulting to better growth and performance. 17

In the present study, FCR was at the lowest in broilers fed by chamomile extract. These results proved that chamomile though being more effective performed to certain extent and have a great potential to be utilized as an alternative. Rayne et al. showed that sumac extracts have been found to have antimicrobial, hypoglycemic and antioxidant activities and its lead to better growth and performance for broilers. ${ }^{18}$
Data from (Table 2) showed significant differences for live weight $(\mathrm{g})$ between treatments. In this case the higher live weight was for S2 and the lesser was for control group.

Results of some researcher study showed that weights, feed conversion ratios (FCR) and dressing percentages (DP) increased $(\mathrm{P}<0.05)$ in birds supplemented with herb extract compared to control birds and mortalities and sudden deaths were minimized via herbal supplementation.5,19

Weiner reported that some plants or specific combinations of herbs in formulations may act as antioxidants by exerting superoxide scavenging activity or by increasing superoxide dismutase activity in various tissue sites. ${ }^{20}$

Zhian et al. ${ }^{21}$ showed that all treatments revealed to chamomile plant had no significant differences on dressing percentage and giblets weight except thighs drumsticks, and heart weight increased significantly $(\mathrm{P} \leq 0.05)$. These results are in agreement with researchers who indicated that, addition of medicinal herbal plants had a significant effect on improving digestibility coefficient and nutritive values. ${ }^{11,22}$

Table 1. Composition of the experimental diets for broiler chicks.

\begin{tabular}{lcccc}
\hline Ingredients \% & $\begin{array}{c}\mathbf{0 - 7} \\
\text { (days old) }\end{array}$ & $\begin{array}{c}7-14 \\
\text { (days old) }\end{array}$ & $\begin{array}{c}15-29 \\
\text { (days old) }\end{array}$ & $\begin{array}{c}29-42 \\
\text { (days old) }\end{array}$ \\
Corn grain & 52.22 & 53.30 & 49.25 & 43.20 \\
Soybean meal & 37.5 & 33 & 27 & 23.5 \\
\hline Wheat & 6 & 10 & 20 & 30 \\
Calcium Carbonate & 1.60 & 1.50 & 1.55 & 1.40 \\
\hline Nacl & 0.18 & 0.20 & 0.20 & 0.20 \\
Vitamin Premix* & 1.25 & 1 & 1 & 0.85 \\
\hline Mineral Premix* & 1.25 & 1 & 1 & 0.85 \\
Calculated nutrient content & & & & \\
$\quad$ ME(Kca/Kgr) & 2830 & 2870 & 2920 & 2960 \\
$\quad$ CP (\%) & 22 & 20.5 & 18.5 & 17.5 \\
$\quad$ Ca (\%) & 1 & 0.95 & 0.85 & 0.85 \\
$\quad$ Available Phosphorus (\%) & 0.50 & 0.45 & 0.45 & 0.40 \\
$\quad$ Lysine (\%) & 1.34 & 1.20 & 1.05 & 0.95 \\
$\quad$ Methionine+Cystine (\%) & 0.92 & 0.85 & 0.80 & 0.75 \\
\hline
\end{tabular}

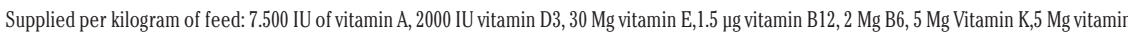

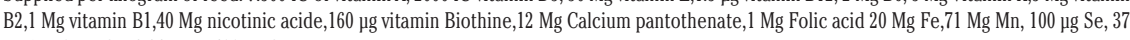
$\mathrm{Mg} \mathrm{Zn}, 6 \mathrm{Mg} \mathrm{Cu}, 1.14 \mathrm{Mg} \mathrm{I}, 400$ pg Cu.

Table 2. The effect of added experimental diets on broilers performance.

\begin{tabular}{lccccc} 
Treatments & FI $(\mathrm{g} / \mathrm{d})$ & BW $(\mathrm{g} / \mathrm{d})$ & FCR & live weight $(\mathrm{g})$ & Carcass yield $(\mathrm{g})$ \\
Control & $102.50 \mathrm{c}$ & $49.70^{\mathrm{c}}$ & $2.04^{\mathrm{a}}$ & $2088.30^{\mathrm{c}}$ & $1424.40 \mathrm{c}$ \\
S1 & $103.30^{\mathrm{b}}$ & $52.11 \mathrm{ab}$ & $1.95^{\mathrm{b}}$ & $2189.40 \mathrm{ab}$ & $1526.80^{\mathrm{ab}}$ \\
\hline S2 & $104.40^{\mathrm{b}}$ & $53.50^{\mathrm{a}}$ & $1.93^{\mathrm{b}}$ & $2249.80^{\mathrm{a}}$ & $1587.50^{\mathrm{a}}$ \\
S3 & $103.22^{\mathrm{bc}}$ & $51.30^{\mathrm{bc}}$ & $1.90^{\mathrm{b}}$ & $2189.35 \mathrm{bc}$ & $1490.90^{\mathrm{bc}}$ \\
\hline Pvalue & 0.021 & 0.011 & 0.022 & 0.089 & 0.060 \\
\hline
\end{tabular}

Means within row with no common on letter are significantly different $(\mathrm{P}<0.05)$. 


\section{Edible organs weight}

According to data from Table 3, using of different levels of chamomile extracts lead to decrease abdominal fat statistically $(\mathrm{P}<0.05)$. Also, liver weight was higher were broilers fed with S2 $(\mathrm{P}<0.05)$ and intestine weight was at the highest for $\mathrm{S} 3$ than others.

Abazaet al. ${ }^{23}$ demonstrated that chamomile powder at levels of $4 \mathrm{~g} / \mathrm{kg}$ were significantly increased percentage of bursa of fabercius weight $(\mathrm{P}<0.05)$. Also, they noted that improvement in immune responses of broiler chicks by chamomile flower is related to inhibit the harmful intestinal microorganisms, thus counter acting excessive growth. Antimicrobial substances are present in cinnamon can reduce the harmful bacteria populations in the gastrointestinal tract and improve the levels of absorbed amino acids. 15,24

Data from Table 4 showed that triglyceride, cholesterol and LDL tended to decrease by using chamomile alcoholic extract and HDL increased significantly $(\mathrm{P} \leq 0.05)$.

The supplemented broiler diets with chamomile essential oil have a beneficial effect on broiler performance and plasma cholesterol and glucose. ${ }^{25}$ As result relieved from Al-Moramadhi et al. ${ }^{19}$ study significant decrease $(\mathrm{P} \leq 0.05)$ in glucose and cholesterol concentration was showed in treatments compared with the control.

Cemeck et al. 26 found that the ethanolic extract of chamomile inhibit the formation of free radicals and may scavenge the reactive oxygen metabolites through various antioxidants compounds in them. In another hand Fiddler et al.27 found that chamazulene, the active ingredient in chamomile effect free radical processes and inhibit lipid per oxidation.

Phenolic compounds that found in some herbals inhibit lipid per oxidation, scavenge the superoxide anion and hydroxyl radical described by other researchers (Table 5).2,28 Additionally could enhance the activities of detoxifying enzymes such as glutathione-Stransferase.23,29 For example D-limonene (1methyl-4-(1-methylethenyl)-cyclohexane) is a monocyclic monoterpene component of sumac that has hypo-cholesterolemic effects. ${ }^{3}$

Table 3. The effect of added experimental diets on some edible organs.

\begin{tabular}{lcccc} 
Treatments & Liver $(\mathrm{g})$ & Abdominal Fat $(\mathrm{g})$ & Spleen $(\mathrm{g})$ & Intestine $(\mathrm{g})$ \\
Control & $40.55^{\mathrm{b}}$ & $43.80^{\mathrm{a}}$ & $1.85^{\mathrm{a}}$ & $78.20 \mathrm{c}$ \\
S1 & $43.20^{\mathrm{ab}}$ & $42.32^{\mathrm{ab}}$ & $1.90^{\mathrm{a}}$ & $79.30^{\mathrm{b}}$ \\
\hline S2 & $44.54^{\mathrm{a}}$ & $41.60^{\mathrm{ab}}$ & $1.76^{\mathrm{b}}$ & $80.00^{\mathrm{a}}$ \\
S3 & $43.11 \mathrm{ab}$ & $30.80^{\mathrm{c}}$ & $1.70^{\mathrm{b}}$ & $81.50 \mathrm{a}$ \\
\hline P value & 0.030 & 0.024 & 0.025 & 0.052
\end{tabular}

Means within row with no common on letter are significantly different $(\mathrm{P}<0.05)$.

Table 4. The effect of added experimental diets on some blood parameters (mg/dL).

\begin{tabular}{lcccc} 
Treatments & Triglyceride & Cholesterol & LDL & HDL \\
Control & $70.55^{\mathrm{a}}$ & $134.00^{\mathrm{a}}$ & $60.00^{\mathrm{a}}$ & $67.20^{\mathrm{c}}$ \\
S1 & $69.25^{\mathrm{b}}$ & $133.55^{\mathrm{b}}$ & $58.95^{\mathrm{b}}$ & $69.10^{\mathrm{b}}$ \\
\hline S2 & $68.09^{\mathrm{b}}$ & $132.90^{\mathrm{b}}$ & $57.26^{\mathrm{b}}$ & $70.11^{\mathrm{a}}$ \\
S3 & $67.45^{\mathrm{c}}$ & $131.25^{\mathrm{c}}$ & $56.65^{\mathrm{c}}$ & $71.02^{\mathrm{a}}$ \\
\hline Pvalue & 0.022 & 0.036 & 0.040 & 0.26 \\
\hline
\end{tabular}

Means within row with no common on letter are significantly different $(\mathrm{P}<0.05)$.

Table 5. The effect of used experimental diets on intestinal characteristics of broilers (Micron).

\begin{tabular}{|c|c|c|c|c|c|}
\hline Treatments & $\begin{array}{l}\text { Villus } \\
\text { height }\end{array}$ & $\begin{array}{l}\text { Crypt } \\
\text { depth }\end{array}$ & $\begin{array}{l}\text { Villus } \\
\text { width }\end{array}$ & Epithelium & $\begin{array}{c}\text { Goblet } \\
\text { cells }\end{array}$ \\
\hline Control & $56.95^{\mathrm{a}}$ & $20.14 a b$ & $6.54 \mathrm{c}$ & $2.50^{\mathrm{b}}$ & $4.50 \mathrm{c}$ \\
\hline S1 & $56.32 \mathrm{ab}$ & $20.29 \mathrm{ab}$ & $7.40 \mathrm{ab}$ & $2.84^{a}$ & $5.50^{\mathrm{b}}$ \\
\hline S2 & $55.33^{b}$ & $21.42^{\mathrm{a}}$ & $7.60^{\mathrm{a}}$ & $2.82^{\mathrm{a}}$ & $6.50^{\mathrm{a}}$ \\
\hline S2 & $55.5 \mathrm{l}^{\mathrm{b}}$ & $19.35^{b}$ & $6.680 \mathrm{bc}$ & $2.60^{\mathrm{b}}$ & $6.50^{\mathrm{a}}$ \\
\hline Pvalue & 0.060 & 0.071 & 0.072 & 0.076 & 0.025 \\
\hline
\end{tabular}

Means within row with no common on letter are significantly different $(\mathrm{P}<0.05)$.

\section{Intestinal characteristics}

Using of chamomile extract affect intestinal characteristics such as villus height, crypt depth, villus width, epithelium layer and goblet cells. Villus height was decreased by using S1 and S2.The highest increase for crypt depth was seen on S2. According to these data villus widths, epithelium layer and goblet cells were increased by using chamomile extract specially by using S2.The hypo-cholesterolaemic action of herbals is possibly related to its poly-phenolic components. 8,30 Polyphenols have been shown to depress the reverse-cholesterol transport, reduce the intestinal cholesterol absorption and even increase bile acid excretion. 24,29

\section{Conclusions}

We could be explained that we observed some goods by using chamomile alcoholic extract on performance of Ross 308 broilers. Improvement on performance and growth may be due to some biological functions of that to improve growth or that maybe due to their role as stimulant, enhanced digestibility, anti-oxidant, antimicrobial and properties of them for prevention of gastric toxicity. Although further studies with higher dosage of them are needed to explore and more detail explanation.

\section{References}

1. Zargari A. Medicinal plants. 5th ed. Tehran: Tehran University Press; 1997.

2. Khalaf AN, Shakya AK, Al-Othman A, et al. Antioxidant activity of some common plants. Turkish J Biol 2008;32:515.

3. Kurucu S, Koyuncu M, Guvenc A, et al. The essential oil of Rhuscoriaria L. (sumac). J Essent Oil Res Jeor 1993;5: 481-6.

4. Kolacz R, Switala M, Gajewczyk P. Herbs as agents affecting the immunological status and growth of piglets weaned with body weight deficiency. J Anim Feed Sci 1997;6:269-79.

5. Abo Omar J, Hejazi A, Badran R. Performance of broilers supplemented with natural herb extract. Open J Anim Sci 2016;5:68-74.

6. Kamel C. Tracing modes of action and the roles of plant extracts in non-ruminants. Rec Adv Anim Nutr 2011:13550.

7. Namur AP, Morel J, Bichek H. Compound animal feed and feed addi- 
tives. In: Deboer F, Bichel H, eds. Livestock feed resources and feed evaluation in Europe. Amsterdam: Elsevier; 1998.

8. Pourreza J, Sadeghi G. Management of poultry production. Nasher Ardakan Press. Isfahan, Iran 2008.

9. Harborne JD, Mabray TJ, Mabray H. Physiology and function of flavonoid. New York-San Francisco: The Flavoid Academy press; 1975. pp. 970-1042.

10. NRC. Nutrient requirements of poultry. 9th revised ed. Washington, DC: National Academy Press; 1994.

11. Valiollahi MR, Rahimian Y, Miri Y, et al. Effect of ginger (Zingiber officinale) and black pepper (Piper nigrum L.) powder on performance, hematological parameters and antibody titer in broiler chicks. Res Opin Anim Vet Sci 2014;4:128-32.

12. SAS Institute, SAS/STAT User's guide for personal computer.Release 6.12 SAS Institute, Inc., Cary, N.C., USA 2001.

13. Cabuk M, Bozkurt M, Alcicek A, et al. Effect of herbal essential oil mixture on growth and internal organ weight of broilers from young and old breeder flocks. South Afr J Anim Sci 2006;36:135-41.

14. Skomorucha I, Sosnowka-Czajka E. Effect of water supplementation with herbal extracts on broiler chicken welfare. Ann Anim Sci 2013;13:849-57.

15. Mansoob HN. Effect of different levels of sumac powder (Rhus Coriaria L.) on performance, carcass and blood param- eters of broiler Chickens. Ann Biol Res 2012;2:647-52.

16. Ahmadian-Attari MM, Amin GH, Fazeli MR, Jamalifar H. A review on the antibacterial and effects of sumac fruit. Med Plants 2007;7:1-9.

17. Lee JC, Kim J, Jang YS. Ethanol eluted extract of (Rhus verniciflua) stokes inhibits cell growth and induces apotosis in human lymphoma cells. J Biochem Mol Bio 2003;36:337-43.

18. Rayne S, Mazza G. Biological activities of extracts from sumac (Rhus spp.): a review. Plant Food Hum Nutr 2007;62:165-75.

19. Al-Moramadhi SAH. The effect of aqueous extract of Marticaria Chamomilla flowers on some physiological properties in broiler chickens. Al-Qadisiya J Vet Med Sci 2011;10:5965.

20. Weiner MA. Herbal antioxidants in clinical practice. J Orthomol 1994;9:167-76.

21. Mahmmod ZA. The effect of chamomile plant (Matericaria chamomile L.) as feed additives on productive performance, carcass characteristics and immunity response of broiler. Int J Poultry Sci 2013;12:111-6.

22. Faghani M, Rafiee A, Namjoo AR, Rahimian Y. Performance, cholesterol profile and intestinal microbial population in broilers fed turmeric extract. Res Opin Anim Vet Sci 2014;4:500-3.

23. Abaza IM, Asar MA, El-Shaarrawi GE, Hassan MF. Effect of using Nigella seed, Chamomile flowers, Thyme flow- ers and Harmala seed as feed additives on performance of broiler. Egypt J Agric Res 2003;81:735-49.

24. Ozcan MM, Haciseferogullari H. A condiment sumac (Rhus coriaria L.) fruits: Properties. Bulg J Plant Physiol 2004;30:74-84.

25. Ayad HS. Biochemical studies on chamomile. M.Sc. Thesis, Biochemistry, Faculty of Agriculture, Cairo University, Giza 1998.

26. Cemek M, Kaga S, Sim Seek N, et al. Antihyperglycemic and antoxidative potential of Marticaria chamomilla $\mathrm{L}$ in streptozotocin induced diabetic. J Natl Med 2007;3:228-35.

27. Fiddler P, Lorinzi C, Fallon J. Prospective evolutions of chamomile mouth wash for the prevention of fuinduced oral mucositis. Can Cer 1996;77:523-5.

28. Jung NC. Biological activity of urushiol and flavanoid from Lac tree (Rhus verniciflua Stokes). Ph.D. Thesis Chonnam National University, Kwang-Ju, South Korea 1998.

29. Singh O, Khanam Z, Mesra N, Srivastava MK. Chamomile (Matricariachamomilla L.): An overview. Pharmacogn Rev 2011;5:8295.

30. Tebib K, Bitri L, Besanqon P, Rouanet JM. Polymeric grape seed tannins prevent plasma cholesterol changes in high-cholesterol-fed rats. Food Chem 1994;49:403-6. 